\title{
Applying CLIL to English Language Teaching in Thailand: Issues and Challenges
}

\section{La aplicación del AICLE para la enseñanza del idioma inglés en Tailandia: asuntos y retos}

\author{
Khwanchit SUWANNOPPHARAT \\ Chulalongkorn University, Bangkok, Thailand \\ khwanchit.s@psu.ac.th
}

\author{
Sumalee CHINOKUL \\ Chulalongkorn University, Bangkok, Thailand \\ csumalee@chula.ac.th
}

\begin{abstract}
Most countries in the world have been influenced by the trends of globalization and interculturality; accordingly, the English language and related cultures have come to play more important roles in global communication. Educational research, a primary source for language teaching and learning development, has increasingly emphasized the importance of integrating language and culture in teaching and learning processes. However, it is not easy for students who use English as a foreign language (EFL) to speak English fluently in an environment where English is rarely used outside the classroom. Teachers nevertheless try to find out the most appropriate teaching approach to develop their students' English skills in order to serve the demands for English in the labor markets. This article discusses the application of CLIL in an EFL context-a case study in Thailand - with an emphasis on explanation of CLIL framework and principles and how these are implemented in Thailand as guidelines for developing EFL courses or curriculum. Both advantages and disadvantages of applying CLIL are examined and the difficulties of applying CLIL in the classroom are clarified to help EFL teachers plan their courses more effectively.
\end{abstract}

Keywords: Content and language integrated learning (CLIL); English communication; language teaching and learning; English as a foreign language (EFL) context.

\section{Resumen}

La mayoría de los países en el mundo han sido influenciados por las tendencias de la globalización y la interculturalidad; en consecuencia, el idioma inglés y culturas asociadas han llegado a desempeñar un papel más importante en la comunicación global. La investigación educativa, una fuente primaria para la enseñanza de idiomas y el desarrollo de aprendizaje, ha destacado cada vez más la importancia de integrar la lengua y la cultura en los procesos de enseñanza y aprendizaje. Sin embargo, no es fácil para los estudiantes que utilizan el inglés como lengua extranjera (EFL) hablarlo con fluidez en un entorno en el cual se utiliza la lengua muy poco fuera del aula. Los profesores, sin embargo, buscan encontrar el método de enseñanza más adecuado para desarrollar habilidades en el inglés de sus estudiantes con el fin de atender las demandas para inglés en los mercados laborales. En este artículo se analiza la aplicación de AICLE en un contexto EFL—de un estudio de caso en Tailandia-con un énfasis en la explicación del marco y los principios del AICLE y cómo se implementan en Tailandia como directrices para el desarrollo de cursos de inglés como lengua extranjera o de los planes de estudios. Ambas ventajas y desventajas de la aplicación del AICLE se examinan y se aclaran las dificultades para aplicar el AICLE en el aula para ayudar a los profesores de EFL a planificar sus cursos de manera más efectiva.

Palabras clave: aprendizaje integrado de contenidos y lenguas extranjeras (AICLE); comunicación en inglés; enseñanza y aprendizaje de idiomas; contexto del inglés como lengua extranjera.

Received: 2015-03-31 / Sent for peer review: 2015-04-05 / Accepted by peers: 2015-06-27 / Approved: 2015-06-28

To reference this article / Para citar este artículo

Suwannoppharat, K. \& Chinokul, S. (2015). Applying CLIL to English language teaching in Thailand: Issues and challenges. Latin American Journal of Content and Language Integrated Learning, 8(2), 237-254. doi:10.5294/laclil.2015.8.2.8 


\section{INTRODUCTION}

There is no perfect teaching approach guaranteed to work every time with every student in an English as a foreign language (EFL) learning environment (Garrido, 2000; Lawson, 2002). Therefore, one of the main responsibilities of efficient EFL teachers is to identify the context and then select the most appropriate approach for supporting students' learning. As there has been high demand for English communication ability in Thailand due to the growth of international sectors, various teaching approaches have been implemented to develop English skills with Thai students. However, it is not easy to encourage Thai students' English ability in the unsupportive learning environment, in which the Thai language is the sole official and national language (Noom-ura, 2013; Samawathdana, 2010).

Thailand is an EFL country in Southeast Asia in which English is taught as the first foreign language in every educational institution. Thai National Compulsory Education prescribes that Thai students must study English in both compulsory and elective courses for at least 12 years (6-year primary education and 6-year secondary education), excluding kindergarten-level study, before entering university. Although all Thai EFL students spend 12 years learning English in primary and secondary schools, the results of this 12 -year learning remain problematic (Noom-ura, 2013, p. 139).

The Education First EF English Proficiency Index (2014) ranked Thailand in 48th place out of 60 non-majority native English-speaking countries, placing it in the very low proficiency category. According to National Institute of Educational Testing Service (2015), the scores on the Ordinary National Education Test (O-NET) administered in 2015 were lower than the test scores administered in the previous years; the mean score is 23.44 out of 100 , with maximum and minimum scores at 99.00 and 1.00 respectively. As the O-NET is a standard placement test used as one of the criteria for entering any program in Thai public universities, it is possible to 
express that the average English proficiency of Thai freshmen entering at the tertiary level is rather low.

While Thai students' English proficiency levels have gradually decreased, there is nevertheless high demand for high levels of English proficiency in Thailand, since Thailand is one of Association of Southeast Asian Nations (ASEAN) members aiming to establish a single market and production base among ASEAN countries (Association of Southeast Asian Nations, 2009), in which English is used a common medium of communication. Consequently, the Thai government has promoted English development campaigns through the activities of the Thai Ministry of Education (such as English Day and English Zone) to encourage the development of Thai students' English abilities.

Dhanasobhon (2006) argues that one of main factors behind the English language teaching and learning failures in Thailand is the lack of opportunities for student exposure to English outside of class time. As a result, a variety of self-learning resources have been provided to support language learning outside the classroom to help students communicate more fluently in real society (even if the national medium of communication is solely Thai). Given that these self-learning resources depend heavily on information and communication technologies (ICTs), due to insufficiently developed infrastructure, students in rural and remote areas often cannot use any the self-learning resources; these thus seem ineffective tools for this situation. Most Thai educational institutions have employed native speakers to give students opportunities to practice more English skills and activate confidence in using English in their daily lives; however, some institutions cannot do this because of the lack of financial support. Thus, effective communication abilities are often achieved by Thai students only with much difficulty through selfstudy activities outside the classroom. Moreover, globalization has raised awareness of the importance of diverse cultures and has brought people from all around the world to the same circle of English-language 
communication. Accordingly, there is ever greater emphasis in the importance of teaching and learning English processes in Thailand.

It seems that self-study English learning will remain difficult to achieve in Thailand since it depends on numerous often lacking factors, such as learners' concentration, financial support, and advanced technology — as well as time - for success in developing Thai students' abilities to apply their English skills in their daily lives. Consequently, we would argue that there should be a greater focus on in-class learning, where the scope is smaller, and the teacher can more easily plan, control, and adjust all elements of the teaching and learning processes to make them a better resource of English knowledge for the students. If English teaching and learning is managed effectively and successfully, then learners should be able to apply their knowledge of English for the real communicative purposes that society demands. Thai English teachers must thus find a teaching approach well-suited to fulfil all the demands - that learners have high levels of English proficiency, are knowledgeable in subject content, can apply all steps of thinking in cognitive processes, have the ability to communicate with others, and can present their own cultures and learn about other cultures - and encourage the use of English as a medium of communication. The approach selected to achieve this should provide opportunities for the students to be exposed to English communication in the class that increases their confidence in using English.

Content and Language Integrated Learning (CLIL) seems to be a teaching approach that meets all of these demands. Graddol (2006) and Mephisto, Frigols, and Marsh (2008) argue that CLIL is the ultimate communicative methodology, engaging active student participation to develop their capabilities to acquire knowledge and skills through cognitive processes. The students are also encouraged to learn language skills through multiple forms of instructional activities. Moreover, Coyle, Hood, and Marsh (2010), Dalton-Puffer and Smit (2007), Marsh (2002), Nikula (2010), and Nowak (2011) agree that CLIL is an appropriate approach to teaching English in EFL contexts. 
It is an innovative educational approach that has emerged to meet the demands of a globalized and integrated world in which learning and teaching content and language takes place through the use of an additional language.

The CLIL approach was first applied in English classes in Thailand in 2006, through cooperation between the Thai Ministry of Education and the British Council in efforts to improve Thai educational outcomes (MacKenzie, 2008). The first CLIL project, administered in September 2006, showed that the CLIL approach was useful for language learning in the Thai context. The English skills of students in the project were improved, and they had positive attitudes towards learning language. The 2 of 4 main vision statements for Thailand in 2025 are that 1) English will be one of core languages, and 2) school students will learn through CLIL approach with appropriate standards-based assessment methods through the use of ICTs (British Council, 2006; MacKenzie, 2008). We would predict that CLIL can be shown to work effectively in the Thai context because the main role of the teacher in the CLIL classroom is that of a facilitator who helps encourage the students' learning, both individual and group learning processes, to acquire knowledge, power of perception, communication, and reasoning. Dalton-Puffer (2011) notes:

CLIL languages tend to be recruited from a small group of prestigious languages, and outside the English-speaking countries, the prevalence of English as a CLIL medium is overwhelming. Therefore, most of the time CLIL effectively means CEIL, Content-and-English Integrated Learning. (p. 183)

In Thailand, certainly, the application of CLIL means CEIL, and teachers of English are normally non-native speakers.

\section{WHAT IS CLIL?}

Content and Language Integrated Learning (CLIL) is "a dual-focused educational approach in which an additional language is used for the 
learning and teaching of both content and language" (Coyle, Hood, \& Marsh, 2010, p. 1; Marsh, 2012). Therefore, language teachers in CLIL programs have a very important and difficult task: they have to know the language as well as the content of the subject at a sufficient level (Mehisto, Marsh, \& Frigols, 2008). CLIL is content-driven because it involves learning content through an additional language (Coyle, 2011; Coyle et al., 2010; Dalton-Puffer \& Smit, 2007; Eurydice, 2006; Garrido, 2000) that also relates to culture, environment, and learning (Dalton-Puffer, 2011; Jappinen, 2005) based on connected pedagogies and using contextual methodologies (Coyle et al., 2010).

\section{CLIL FRAMEWORK}

The main focus of CLIL approach is the 4Cs Framework, as illustrated in Figure 1.

\section{FIGURE 1. The 4Cs Framework of CLIL}

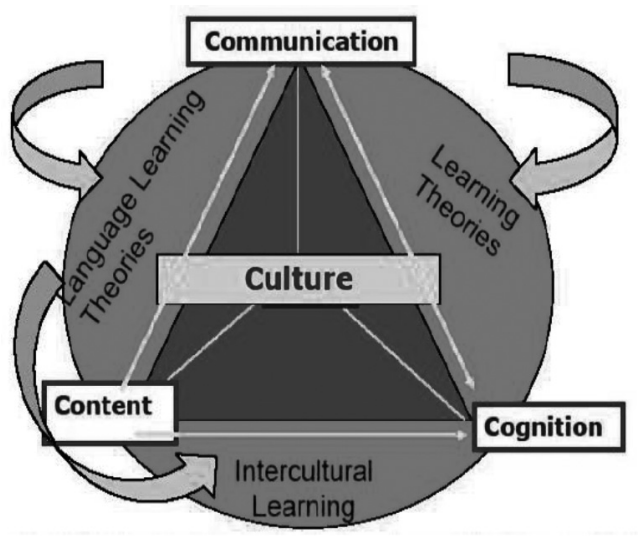

Source: Adapted from Coyle (2011).

This framework consists of 4 dimensions: Content (subject matter), Communication (learning through interaction), Cognition (learning and thinking processes), and Culture (intercultural understanding and global awareness in building up cooperation in learning). Culture permeates the other elements and can reinforce CLIL as a type of instruction that fuses the best of subject matter and language teaching 
pedagogies (Morton, 2010, p. 97). CLIL merges learning theories, language learning theories, and intercultural understanding (Coyle, 2011). It is an example of higher-level interdisciplinary integration and often includes transdisciplinary integration (Coyle et al., 2010). It focuses on the message (topic, content), medium (language), and social interaction with others (Vilkancience, 2011).

To achieve quality CLIL, teachers have to consider the core elements of CLIL — content, language, integration and learning — which are realized through the set of the 4Cs. Moreover, to succeed in CLIL practice, there is a requirement for teachers to engage with alternative ways of planning for effective teaching. Furthermore, CLIL lessons should include a variety of different activities to promote necessary knowledge and also develop students' communicative competence (Klimova, 2012). As CLIL implementation can offer numerous advantages, teachers who desire to be successful in CLIL classrooms should follow the main principles of CLIL (Mehisto et al., 2008):

1. Authenticity: The use of authentic materials, authentic case and authentic content from the real world such as daily newspapers, brochures, flight attendance in airline business courses/topics.

2. Multiple focus: The use of a variety of activities helps develop the students' several skills at the same time. Automatic learning will occur.

3. Active learning: The students are active in both the preparation and presentation stages. The teacher has to encourage the students to take a role in all steps of learning. Participation can activate active learning.

4. Safe learning environment: Familiar classroom setting and peer participation help the students feel safe and learn new things without less worry.

5. Scaffolding: The teacher is a facilitator and peers are consultants through class discussion. The teacher has to be ready to help the students all the time and also to encourage them to be good peers in helping each other to learn. 
Effective CLIL occurs as a result of the symbiosis through progression in knowledge, skills, and understanding of content, engagement in associated cognitive procession, interaction in the communicative context, development of appropriate language knowledge and skills, and the acquisition of a deepening intercultural awareness - this last of which is in turn brought about by the positioning of self and other (Coyle, 2011; Coyle et al., 2010).

\section{CLIL AND CBI}

There has been confusion about the differences between CLIL and CBI (Content-Based Instruction), and many scholars have debated the similarities and differences between CLIL and CBI (see, for example, Cenoz, Genesee, \& Gorter, 2013; Dalton-Puffer, Llinares, Lorenzo, \& Nikula, 2014).

In the present study, our stance is that $\mathrm{CBI}$ is an approach situated under the umbrella of Communicative Language Teaching (CLT). $\mathrm{CBI}$ is, "the teaching of content or information in the language being learned with little or no direct or explicit effort to teach the language itself separately from the content being taught" (Richards \& Rogers, 2001, p. 204). The use of content topics is more emphasized than grammatical rules or vocabulary pedagogy (Duenas, 2004; Elhoseiny, 2008). Differences between CBI and CLIL are set out in Table 1.

According to Hirvela (2011), both CLIL and CBI are managed on the same core principles, but CLIL represents a more elaborated application of CBI. CLIL promotes and fosters linguistic diversity in ways that transcend the more survival-oriented nature of CBI; CLIL enhances more opportunities for interaction than CBI.

\section{Advantages and disadvantages of CLIL}

A great deal of CLIL research suggests that CLIL can help improve overall competence in the target language because it encourages teachers to prepare students for internationalization by developing their content knowledge through the medium of other languages, improve 
Table 1. Differences between CLIL and CBI

\begin{tabular}{|c|c|c|}
\hline Focus & CLIL & CBI \\
\hline $\begin{array}{l}\text { Medium of } \\
\text { instruction in } \\
\text { EFL classrooms }\end{array}$ & $\begin{array}{l}\text { Language used in the classroom } \\
\text { is not regularly used in the wider } \\
\text { society of learners. } \\
\text { The target language is used } \\
\text { purely in the classroom. }\end{array}$ & $\begin{array}{l}\text { Language used in the classroom } \\
\text { is probably used in the wider } \\
\text { society of learners. } \\
\text { Bilingualism may be implemented } \\
\text { in the classroom. }\end{array}$ \\
\hline Teachers & $\begin{array}{l}\text { Teachers are non-native speakers } \\
\text { of the target language. }\end{array}$ & $\begin{array}{c}\text { Teachers are probably native } \\
\text { speakers of the target language. }\end{array}$ \\
\hline Framework & $\begin{array}{c}\text { The } 4 \mathrm{Cs}-\text { Content, } \\
\text { Communication, Cognition, and } \\
\text { Culture. }\end{array}$ & Content and language. \\
\hline Goal & $\begin{array}{c}\text { Emphasis on intercultural } \\
\text { knowledge, understanding, and } \\
\text { communication. }\end{array}$ & $\begin{array}{c}\text { Emphasis on the acquisition of } \\
\text { academic content and related } \\
\text { language. }\end{array}$ \\
\hline
\end{tabular}

Source: Based on Dalton-Puffer, Nikula \& Smit (2010); Lasagabaster (2008); Richards \& Rogers (2001); Wolff(2007).

specific language expressions, express intercultural communicative competences, and activate a high level of communication between teachers and learners (and among themselves). In addition, a variety of teaching methods used in the CLIL classroom also helps increase learners' motivation (Bruton, 2011; Costa, 2009; Lasagabaster, 2008; Marsh, Maljers, \& Hatiala, 2001; Darn, 2006).

In the CLIL classroom, students have to work cooperatively with others, making use of each person's strengths and weaknesses, and operating effectively in groups. This promotes the development of lifeskills such as dealing with unexpected events, observational skills, and constructing knowledge built on interaction with the world (Coyle et al., 2010).

However, despite numerous benefits of CLIL, there are some challenges that we have to consider before planning to use it in the classroom. For example, a CLIL course requires teachers who are knowledgeable in both content and language. If the language teachers are not expert at the content being taught, it will not be easy for them to manage the class and follow the planned steps in the lesson plan; this may cause unenjoyable learning activities. Moreover, the 
4Cs framework, though the core pattern for planning CLIL teaching activities, can also be an obstacle, since teachers have to ensure that the selected content and activities provided for students' learning appropriately integrate the 4Cs so as to enhance the effectiveness of the CLIL approach-otherwise, there is little theoretical backing to assure effectiveness. Additionally, insufficient commercial CLIL learning materials are readily available to support the CLIL classroom, meaning that teachers have to create their own materials or adapt existing materials to fit the 4Cs framework that a good plan requires.

Therefore, it can be concluded that there are many factors that have an influence on successful implementation of CLIL. The teacher is an important factor in processing the CLIL classroom; therefore, it is important that teachers be trained and qualified in CLIL concepts by participating in CLIL professional development projects. Qualified CLIL teachers are likely to be more successful in overcoming challenges presented by either students' personalities or the overall educational environment.

\section{CLIL IMPLEMENTATION IN THAILAND}

According to Prasongporn (2009), writing after the launching the CLIL pilot project in Thailand, CLIL can indeed be an effective approach to language learning in a Thai context; however, CLIL module design is time-consuming. Nevertheless, results from the first CLIL project administered by the Ministry of Education and British Council show that Thai students had a positive attitude towards CLIL (British Council, 2006; Prasongporn, 2009; Samawathdana, 2010), which is a good enough starting point to improve learning effectiveness. Active participation in CLIL modules encourages students to become more interactive and teachers to be more satisfied, since cooperation and collaboration with learning in CLIL encourages students to learn to solve problems and work with others. Content teachers had more chances to learn English, and English teachers learned more about content. 
There are many other studies on CLIL in the Thai context that demonstrate the effectiveness of the CLIL approach. For example, Phoodokmai (2011) developed an English for Academic Purposes course based on the CLIL approach to enhance the reading and writing skills of undergraduates at Udon Thani Rajabhat University by using achievement tests, unit/lesson plans, observation forms, and learning logs. The findings of this study show that, based on the results of the post-test, the CLIL/EAP course enhanced the students' reading and writing skills. Moreover, learning engagement in classroom activities was also activated by the CLIL approach, and student attitudes toward studying the EAP course were positive after the use of the CLIL approach. In another study, Samawathdana (2010) implemented CLIL with Experiential Learning Theory, focusing on development of an instructional model to enhance healthy behaviors and English communication ability amongst Thai lower secondary school students. The findings showed that after the experiment the students had a higher level of English communication ability, as well as more positive attitudes towards learning English communicative skills. As a result, many CLIL studies are now being conducted progressively to encourage Thai students' language learning so that they can use English fluently in their communication within an international context.

\section{Issues and challenges}

The framework and principles of CLIL present a number of issues and challenges towards CLIL application in Thai language classrooms. Firstly, the dual focus of CLIL seems to be both an issue and a challenge, since it not easy for language teachers to teach content and vice versa. Therefore, professional development projects for both Thai content teachers and language teachers are required. The CLIL approach represents the most up-to-date teaching approach that has yet been tried in Thailand; it has been less than a decade since CLIL and its complex principles began to be trialed in the country, where there are as yet few CLIL experts. Therefore, there have rarely been 
CLIL seminars or workshops for teachers in Thailand. However, there have increasingly been people who are interested in applying the CLIL approach in their classrooms, as can be seen from the increasing number of research studies in Thailand relating to the CLIL approach.

Secondly, as CLIL is content-driven and involves learning content through an additional language, it is not easy for Thai teachers to use English as a medium of instruction; nor is it easy for native Thai-speaking students who rarely use English in their daily lives to learn content through English smoothly. Yet CLIL teachers must plan to overcome these challenges. Dhanasobhon (2006) claimed that there is a shortage of teachers of English at secondary level in Thailand because graduates comfortable with English prefer to work in other, higher-salaried jobs, such as flight attendants or with private companies. Noopong (2002) found that $65 \%$ of primary school English teachers did not major in English langauge studies; only 3\% of teachers in primary schools are qualified English teachers. Most Thai students rarely communicate in English, either inside or outside of the classroom.

Thirdly, the main focus of CLIL - the 4Cs Framework-represents another issue and challenge, as planning effective teaching and learning processes through the 4Cs requires a considerable amount of time, during which many obstacles may arise. The lack of training on applying the CLIL approach in classroom represents a significant challenge for Thai English teachers attempting to design any courses based on CLIL. To be sure, Thailand needs to invest considerable time in CLIL preparation - and not only with regard to teachersto make its vision statement for 2025 come true. Indeed, it is worth alerting the Thai government to the fact that Thailand is not-yetready to apply CLIL approach in its national policy or vision.

\section{CONCLUSION}

Students can achieve successful language learning when they receive good instruction and practice in real-life situations through which they can acquire the target language more naturalistically (Coyle 
et al., 2010). CLIL can offer a more natural situation for language development which also builds up forms of content learning (Marsh, 2000), since the CLIL approach focuses on meaning rather than form, and on fluency rather than accuracy (Cendoya \& Bin, 2010). Learner motivation is likewise supported by the natural use of language; therefore, naturalness is of major importance in CLIL as something that contributes to learners' success in both language and subject learning (Marsh, 2000). Successful CLIL classes not only depend on active learners but also on enthusiastic teachers to facilitate in providing scaffolding for their students. When its application has been well planned and prepared for, the CLIL approach helps produce life-long learners who learn about the real world, are motivated toward that learning, and who have the self-confidence to be strong communicators and collaborators in the real-world.

\section{REFERENCES}

Association of Southeast Asian Nations. (2009). Roadmap for ASEAN community. Bangkok, Thailand: ASEAN.

British Council. 2006. Future perfect-English language policy for global transition conference report. Retrieved from the British Council Thailand website: http://my.britishcouncil.or.th/upload/futureperfect/statement-of-conference-outcomes.pdf

Bruton, A. (2011). Is CLIL so beneficial, or just selective? Reevaluating some of the research. System, 39(4), 523-532. http:// dx.doi.org/10.1016/j.system.2011.08.002

Cendoya, A. M., \& Di Bin, M. V. (2010).A CLIL experience based on the use of tasks and different genre types. Latin American Journal of Content and Language Integrated Learning, 3(1), 11-17. http:/ / dx.doi.org/10.5294/laclil.2010.3.1.2

Cenoz, J., Genesee, F., \& Gorter, D. (2013). Critical analysis of CLIL: Taking stock and looking forward. Applied Linguistics, 35(3), 243-262. http://dx.doi.org/10.1093/applin/amt011 
Costa, F. (2009). ICLHE/CLIL at the tertiary level of education. Studies about Languages, 15, 85-88.

Coyle, D. (2011, April). Teacher education and CLIL methods and tools. Unpublished seminar presented in Milan, Italy. Retrieved from http://www.cremit.it/public/documenti/seminar.pdf

Coyle, D., Hood, P., \& Marsh, D. (2010). CLIL: Content and language integrated learning. Cambridge, UK: Cambridge University Press. Dalton-Puffer, C. (2011). Content-and-language integrated learning: From practice to principles? Annual Review of Applied Linguistics, 31, 182-204.http://dx.doi.org/10.1017/S0267190511000092 Dalton-Puffer, C., Llinares, A., Lorenzo, F., \& Nikula, T. (2014). “You can stand under my umbrella”: Immersion, CLIL and bilingual education: A response to Cenoz, Genesee \& Gorter (2013). Applied Linguistics, 35(2), 213-218. http:/ /dx.doi.org/10.1093/ applin/amu010

Dalton-Puffer, C., Nikula, T., \& Smit, U. (2010). Charting policies, premises and research on content and language integrated learning. In C. Dalton-Puffer, T. Nikula, \& U. Smit (Eds.), Language use and language learning in CLIL classrooms (pp. 1-22). Amsterdam, the Netherlands: Benjamins.

Dalton-Puffer, C., \& Smit, U. (2007). Empirical perspectives on CLIL classroom discourse. Frankfurt am Main, Germany: Lang.

Darn, Steve. (2006). Content and language integrated learning. Retrieved from the British Council/TeachingEnglish website: https://www.teachingenglish.org.uk/article/content-languageintegrated-learning

Dhanasobhon, S. (2006). English language teaching dilemma in Thailand. Retrieved from the ACIT website: http:// www.curriculumandinstruction.org/index.php?lay=show $\& a c=$ article $\& I d=539134523 \&$ Ntype $=7$

Duenas, M. (2004). The whats, whys, hows and whos of contentbased instruction in second and foreign language education. International Journal of English Studies, 4(1), 73-96. 
Education First. (2013). EF English proficiency index. Retrieved from the Education First website: http://www.ef.de/_/ / /media/ centralefcom/epi/v4/downloads/full-reports/ef-epi-2014english.pdf

Elhoseiny, A. S. (2008, March). Content-based instruction \& its application to Arabic English classroom. Unpublished paper presented at the ISNA Education Forum, Chicago, IL.

Eurydice. (2006). Content and language integrated learning (CLIL) at school in Europe. Brussels, Belgium: Eurydice European Unit. Retrieved from http://www.indire.it/lucabas/lkmw_file/ eurydice/CLIL_EN.pdf

Garrido, M.F.L. (2000). CLIL: Anew approach to TEFL. Unpublished manuscript retrieved from http://www.lara25.com/mywebdisk/ NA-TEFL/NA-assignment.pdf

Graddol, D. (2006). English next: Why global English may mean the end of "English as a foreign language". London, UK: British Council. Retrieved from http://www.britishcouncil.org/learningresearch-english-next.pdf

Hirvela, A. (2011). Writing to learn in content areas: Research insights. In R. M. Manchon (Ed.), Learning-to-write and writing-to-learn in an additional language (pp. 37-60). Amsterdam, the Netherlands: Benjamins.

Jappinen, A. K. (2005). Thinking and content learning of mathematics and science as cognitional development in Content and Language Integrated Learning (CLIL): Teaching through a foreign language in Finland. Language and Education, 19(2), 148-169.

Klimova, B. F. (2012). CLIL and the teaching of foreign languages. Procedia - Social and Behavioral Sciences, 47, 572-576. http:// dx.doi.org/10.1016/j.sbspro.2012.06.698

Lasagabaster, D. (2008). Foreign language competence in Content and Language Integrated courses. The Open Applied Linguistics Journal, 1, 31-42. 
Lawson, L. (2002). Scaffolding as a teaching strategy. Unpublished manuscript retrieved from http://www.ode.state.or.us/ opportunities/grants/nclb/title_iii/2scaffolding-as-a-teachingstrategy.pdf

MacKenzie, A. S. (2008). CLILing me softly in Thailand: Collaboration, creativity and conflict. Retrieved from the One Stop English website: http://www.onestopenglish.com/clil/clil-teachermagazine/your-perspectives/cliling-me-softly-in-thailandcollaboration-creativity-and-conflict/500927.article

Marsh, D. (2000). An introduction to CLIL for parents and young people. In D. Marsh \& G. Lange (Eds.), Using languages to learn and learning to use languages. Jyväskylä, Finland: University of Jyväskylä.

Marsh, D. (2002). CLIL/EMILE - The European dimension: Actions, trends and foresight potential. Jyväskylä, Finland: UniCOM, Continuing Education Centre, University of Jyväskylä. Retrieved from http://ec.europa.eu/education/languages/pdf/doc491 en.pdf

Marsh, D. (2009). CLIL: An interview with Professor David Marsh. A. G. Scott (Ed.) IH Journal of Education and Development, 29. Retrieved from http://ihjournal.com/content-and-languageintegrated-learning

Marsh, D., Maljers, A., \& Hartiala, A.-K. (2001). Profiling European CLIL classrooms: Languages open doors. Jyväskylä, Finland: University of Jyväskyla. Retrieved from http://lakk.bildung. hessen.de/netzwerk/faecher/bilingual/Magazin/mat aufsaetze/clilprofiling.pdf

Mehisto, P., Marsh, D., \& Frigols-Martín, M. J. (2008). Uncovering CLIL: Content and language integrated learning in bilingual and multilingual education. Oxford, UK: Macmillan Education.

Morton, T. (2010). Using a genre-based approach to integrating content and language in CLIL. In C. Dalton-Puffer, T. Nikula \& U. 
Smit (Eds.), Language use and language learning in CLIL classrooms (pp. 81-104). Amsterdam, the Netherlands: Benjamins.

National Institute of Educational Testing Service. (2015). O-Net test results. Retrieved from http://www.dailynews.co.th/Content/ education/308764

Nikula, T. (2010). Effects of CLIL on a teacher's language use. In C. Dalton-Puffer, T. Nikula \& U. Smit (Eds.), Language use and language learning in CLIL classroom (pp. 105-124). Amsterdam, the Netherlands: Benjamins.

Noom-ura, S. (2013). English-teaching problems in Thailand and Thai teachers' professional development needs. English Language Teaching, 6(11), 139-147.

Noopong, D. (2002). English teaching problems and the needs for professional development of teachers of English in education extended schools under the jurisdiction of the Office of Primary Education. Nakhon Ratchasima Rajabhat University, Nakhon Ratchasima, Thailand.

Nowak, S. (2011, July). The need for content and language integrated learning (CLIL) development. Paper presented at the 4th International ALTE Conference: Impact of Language Frameworks on Assessment, Learning and Teaching: Policies, Procedures and Challenges, Jagiellonian University, Kraków, Poland.

Phoodokmai, B. (2011). Development of an English for Academic Purposes course using Content and Language Integrated Learning (CLIL) to enhance reading and writing skills of students at Udon Thani Rajabhat University (Unpublished Master's degree). Chulalongkorn University, Bangkok, Thailand.

Prasongporn, P. (2009, June). CLIL in Thailand: Challenges and possibilities. Unpublished paper presented at the Access English EBE Symposium, Jakarta, Indonesia.

Richards, J. C., \& Rogers, T. S. (2001). Approaches and methods in language teaching ( $2^{\text {nd }}$ Ed.). Cambridge, UK: Cambridge University Press. 
Samawathdana, R. (2010). Development of a health study instructional model using English as a medium based on Experiential Learning Theory and Content and Language Integrated Learning approach to enhance health behavior and English communication ability of lower secondary school students (Unpublished Ph.D. dissertation). Chulalongkorn University, Bangkok, Thailand.

Vilkancience, L. (2011). CLIL in tertiary education: Does it have anything to offer? Studies about Languages, 18, 111-118.

Wolff, D. (2007). CLIL: Bridging the gap between school and working life. In D. Marsh \& D. Wolff (Eds.), Diverse contexts-converging goals: CLIL in Europe. Frankfurt am Main, Germany: Lang. 